\title{
The extension of the lithosphere north of Scotland
}

\author{
Timothy J. Reston \\ Geomar, Kiel Universität, Germany
}

\begin{abstract}
Deep seismic profiles north of Scotland reveal a series of Permo-Mesozoic half-grabens, bound by east-dipping extensional faults. Restored sections, based on a depth migration of the data, are used to investigate the nature of crustal extension in this region. It is shown that the extension of the upper crust can best be explained by a modified domino model. However, the restoration shows that the distribution of extension in the lower crust was probably different from that in the upper crust. Although this could be taken as evidence for lower crustal flow during extension, it can also be explained by the extension of the lower crust along a low-angle shear zone, connecting the upper crustal faults with a region of mantle extension further to the west.
\end{abstract}

\section{Introduction}

Deep reflection profiles recorded offshore the north coast of Scotland (fig. 1) reveal a series of east-dipping normal faults, bounding a series of west-tilted half-grabens (Cheadle et al., 1987). These contain Torridonian (Proterozoic), Devonian and Carboniferous sediments, but the latest phase of extension can be shown to date from the Permo-Triassic, which provides the best constrained sediment fill in the half-grabens (Stein and Blundell, 1990). Beneath the crust, two bands of mantle reflections (one east-dipping and one flat) are observed. Here we investigate the nature of Permo-Mesozoic extension through the use of restored sections.

\section{Construction of restored sections}

The measurement and hence removal of extension requires an accurate depth section. Therefore a depth-migrated profile is used here (see Reston, 1992 for details). The effects of raypath bending are included in depth migration, providing a more accurate two-dimensional section of lithospheric structure than is possible with conventional time migration.

The depth section shows that over most of the profile, the Moho is remarkably flat, and does not rise beneath the overlying basins. The implies that the basins are in regional rather than in local isostatic equilibrium. However, the Moho does rise considerably to form an antiroot to the largest basin (the North Lewis Basin), resulting in the upwarp of the Flannan reflections in the mantle.

Over most of the depth migrated profile, the base of the Permian has a consistent dip (fig. 2b)), implying that the amount of syn-extensional rotation was remarkably constant over the region. Therefore a domino model (in which there is little internal block deformation) may be appropriate, and most of the faults can be modelled as planar (although not parallel). The section is restored simply by rotating the fault blocks as rigid bodies until the base of the Permian is horizontal (fig. 2c)). If the blocks were truly rigid bodies, the base of the blocks would tilt during rotation, with one corner rising and the other falling, creating a space problem (e.g., Wernicke and Burchfiel, 1982). However, Jackson et al. (1988) argue that the fault block's base is thermally controlled, and 


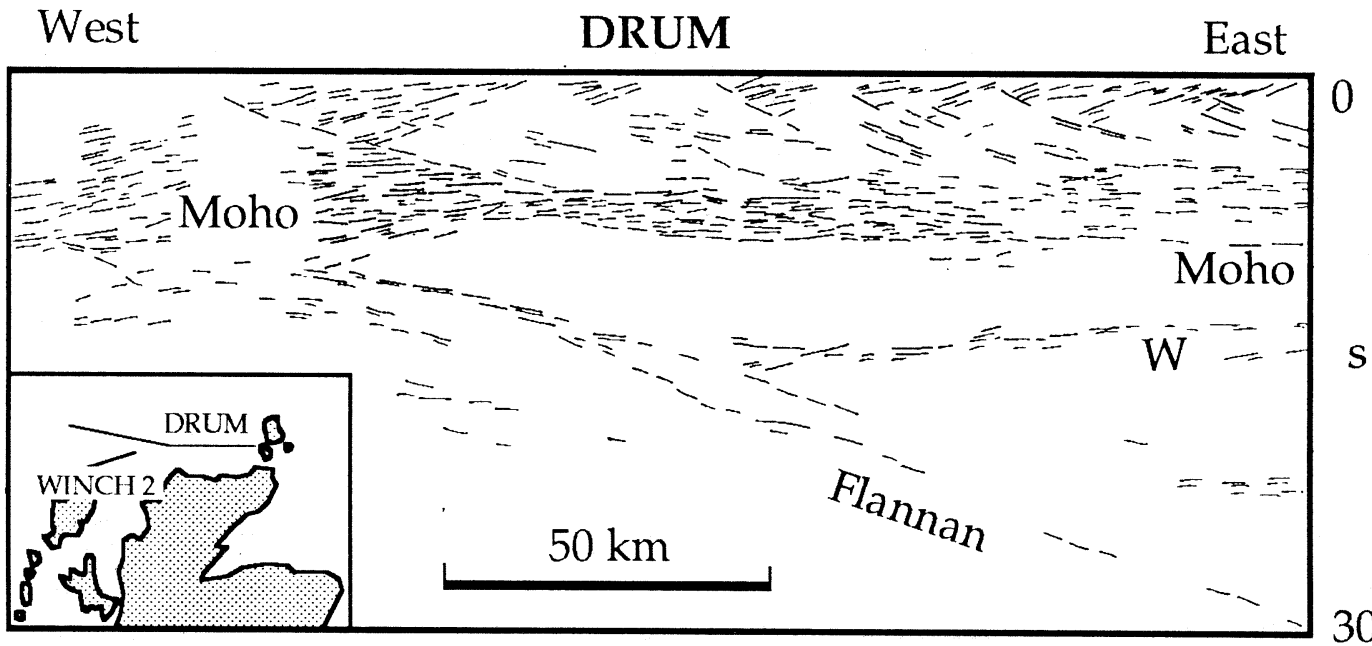

Fig. 1. Line-drawing of the unmigrated DRUM profile to the north of Scotland (Warner and McGeary, 1987). Beneath the Moho reflection, two bands of mantle reflections are observed. One dips to the east (the Flannan), the other is subhorizontal (W). Inset: map of north Scotland showing line locations.

thus migrates during progressive extension and rotation. As the base of the blocks is not a fixed boundary, the top of the lower crust is not a valid marker horizon, but is continually being modified by the brittle faults of the upper crust. This avoids the problem of the keels, but complicates the restoration of the deeper crust. However, it neither affects nor invalidates the amount of extension that can be measured from the upper crust, which depends on the amount of rotation not on the depth to detachment (Jackson et al., 1988).

Wernicke and Burchfiel also point out that in a classic domino model a gap arises where the tilted blocks of the extending region juxtapose the unrifted margin. Footwall uplift and distortion (e.g., Kusznir and Egan, 1989) can fill this gap, but affect the measured extension and the restoration of the section. Thus we must estimate the amount of footwall uplift of the rift margin, in this case the Outer Hebrides block (OHB). The occurrence on the Outer Hebrides of greenschist facies phyllonites formed during post-Caledonian extension (White and Glasser, 1987) indicates that there was about $8 \mathrm{~km}$ of footwall uplift of the OHB at the fault. Using this figure gives a minimum of $45 \mathrm{~km}$ Permo-Mesozoic extension over the whole section. This value is slightly less than implied by previous estimates of the regional stretching factor. (e.g., Cheadle et al., 1987), but reducing the interpreted fault dips and increasing the amount of footwall uplift associated with the Outer Hebrides Block could increase this value by only a few kilometres.

In this modified domino model of Jackson and others, the faults die out downwards as the rigid blocks of the upper crust are replaced by a zone of more pervasive deformation. This means that there is no fixed boundary between the upper and lower crust, and thus no space problem. However, to restore the lower crustal section, it is assumed here that, instead of a gradual transition between the deformational styles of the upper and lower crust, there is some form of boundary zone separating a zone of rigidly rotating fault blocks (the upper crust) from the deeper section. This zone (the base of the dominos) is taken from the seismic section, where it corresponds both to the downward termination of visible faulting, and a gently west-dipping zone of reflections (fig. 2a), b)).

In a first model, it is assumed that the lower crust was extended by the same amount as the overlying upper crust, i.e. that crustal extension was to a first approximation homogeneous. The lower crust is thus divided up into a series of rectangles and polygons attached to the base of 

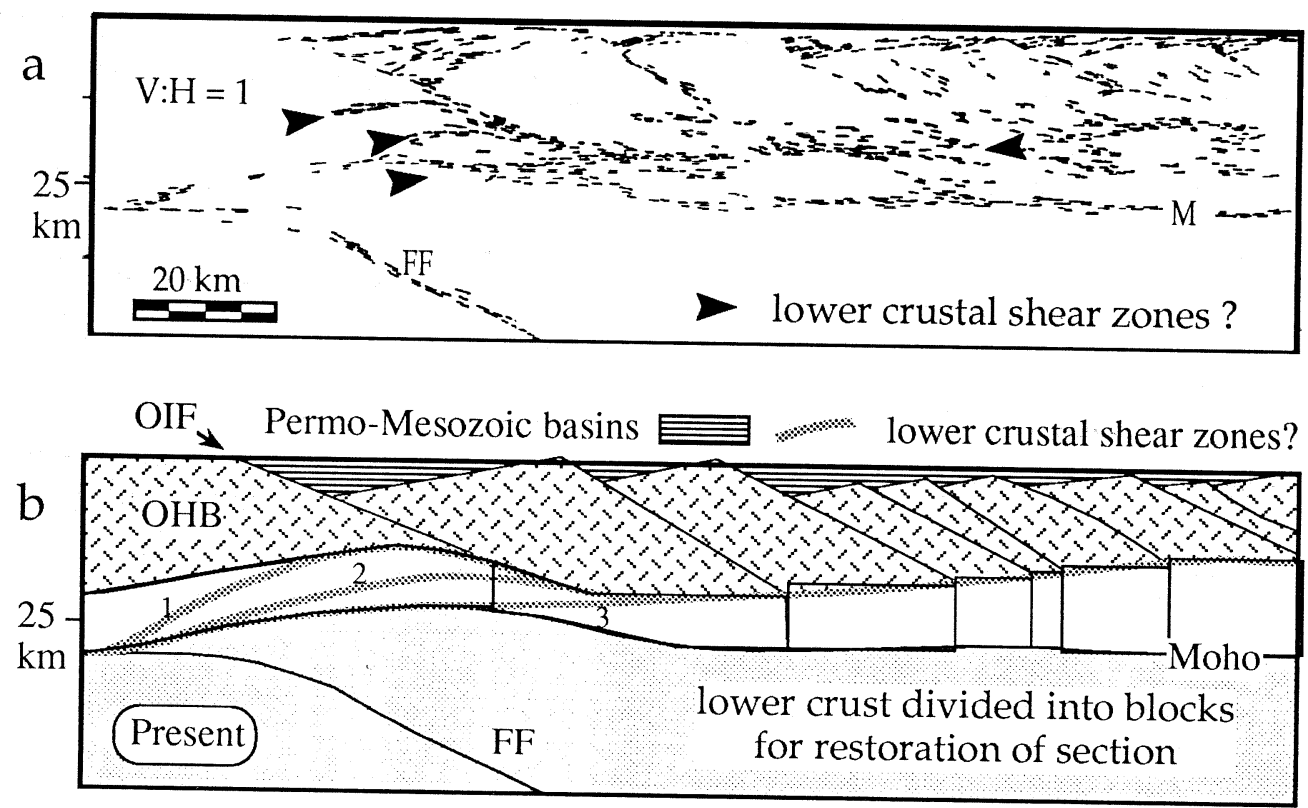

C

$\mathrm{OHB}$ erosion
level $? \rightarrow$
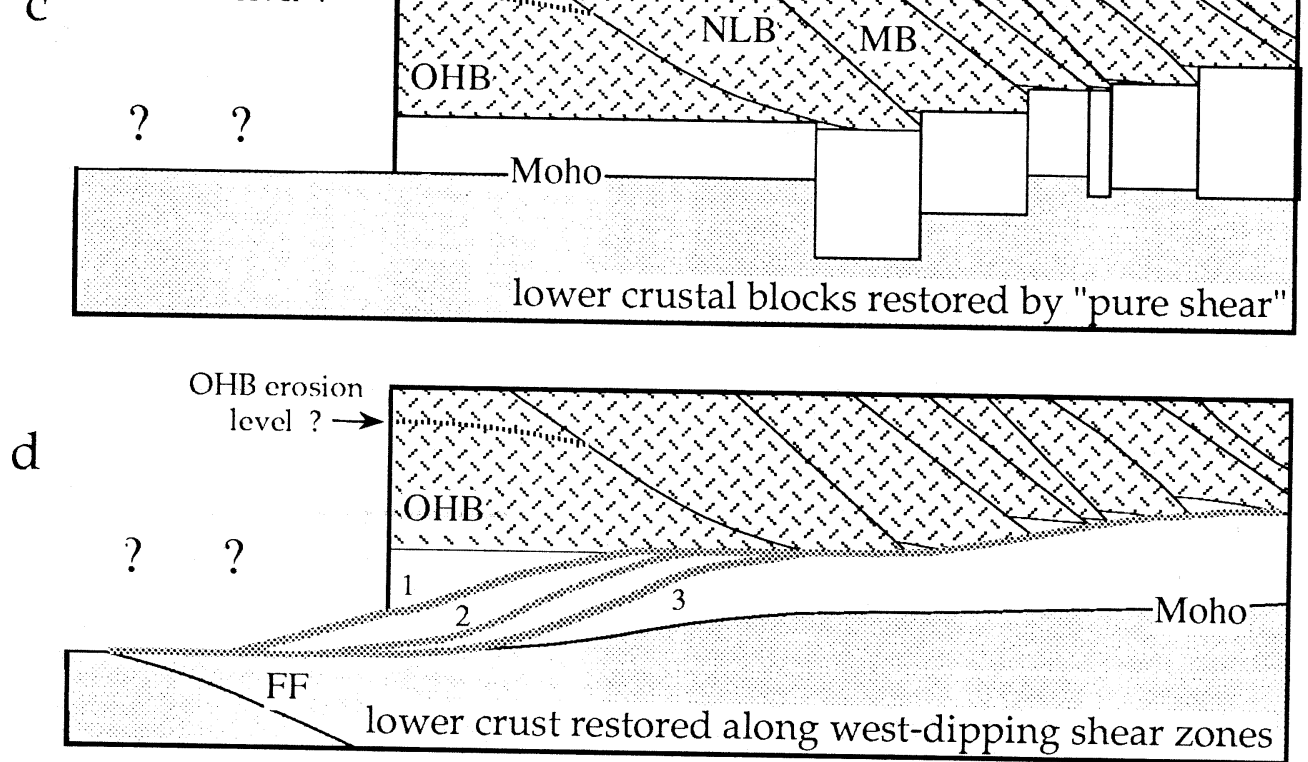

Fig. 2. DRUM depth migrated (a)) interpreted with possible lower crustal shear zones (b)), restored assuming pure shear in lower crust (c)) and restored along west-dipping detachment system in the deep crust (d)). The interpretation with lower crustal shear zones provides a more reasonable restoration of the crustal section, giving a smooth Moho. NLB, North Lewis Block; MB, Minch Block; FF, Flannan; OHB, Outer Hebrides Block; OIF,
Outer Isles Fault. 
each block. These are restored to rectangles of equal area (in most cases by pure shear), as the block is rotated to its Pre-Permian configuration.

The resulting section (fig. 2c)) requires extremely variable crustal thickness prior to extension. Although the eastern portion of the restored crustal section is reasonable, this simple approach predicts that the crustal thickness varied dramatically beneath the Minch and North Lewis blocks prior to Permo-Mesozoic extension. However, the occurrence of thick sequences of Precambrian sediments above these blocks is hard to explain if the crust was locally so thick.

The simple model probably fails as it assumes that crustal extension was homogeneous. Instead, the distribution of lower-crust extension may differ from upper crustal extension, i.e. crustal extension may be strongly heterogeneous, perhaps due to igneous intrusion, lower crustal flow, or some form of detachment system.

Much of the lower crust beneath the North Lewis and Minch blocks could result from igneous additions to the crust. This hypothesis cannot be adequately tested until the velocity structure of the deep crust is known: as yet there is no evidence for such voluminous (half the volume of the lower crust) intrusion into the deep crust north of Scotland.

Alternatively, the lower crust might flow during lithospheric extension (Block and Royden, 1990). Then the lower crust currently beneath the North Lewis Basin block could have flowed there from adjoining regions, removing the need for a locally thick lower crust prior to extension. However, free lower crustal flow should have prevented the development of a basin anti-root beneath the North Lewis Basin and the Outer Hebrides blocks. Furthermore, lower crustal flow would presumably have been subparallel to the lower-crust channel, but a reflective band (arrowed in fig. 2a)) cuts across the lower crust in the region where most of the flow should have taken place.

Meissner and Kusznir (1987) argue that the common occurrence of basin antiroots to the Permo-Mesozoic basins (e.g., the North Sea) of north-west Europe is evidence that the lower crust did not flow significantly during extension. Kusznir and Matthews (1988) point out that the viscosity of the lower crust is probably too high for significant channel flow to occur during rifting, unless the geotherm was unusually hot, or the crust unusually thick (ca. $50 \mathrm{~km}$ ). Although both these conditions are likely to be met elsewhere (e.g., the Basin and Range province), they are less likely to be met beneath the foreland to the Caledonian orogen (the region of the Outer Hebrides and North Lewis blocks) where there is no reason to expect either unusually thick crust or elevated geotherms prior to Permo-Mesozoic extension.

Thus it seems that along this profile the distribution of lower crustal and upper crustal estension must differ, but that lower custal flow may have been insignificant. The simplest way to resolve this paradox is to invoke a lower crustal detachment fault of some kind, which transfers deep crustal extension away from the faults in the upper crust.

McGeary (1989) has shown that a Carboniferous strike-slip fault east of DRUM cuts vertically through the crust, producing a step in the Moho. The preservation of this offset is further testimony to the lack of lower crustal flow in the region, and also means that the extension on DRUM could not have been transferred to the east. Instead, the detachment may cut to the west as some form of gently-west-dipping extensional shear zone. This is consistent with the depth to which the normal faults can be traced: both prior to and after the removal of upper crustal extension, these cut deeper to the west.

Three bands of reflection are interpreted as part of this detachment system (arrowed in fig. 2a) and numbered in fig. 2b), d)). One is the reflective zone which runs along the base of the upper crustal blocks, dipping gently to the west and cutting across the lower crust near the Outer Isles Fault to run along the Moho. The other two bands appear to splay off this west-dipping band just west of the Outer Isles Fault, and are imaged as antiformal features. All three are interpreted as top-to- the-west extensional shear zones, the antiformal bands being earlier detachments, rendered inactive by the uplift of the footwall to the Outer Isles Fault. The third represents the latest stage of the detachment system, active near the end of Permo-Mesozoic extension.

In the model shown in fig. 2d), the restoration of the deeper crustal section was achieved by 
sliding a series of coherent lower crustal slices together along these shear zones (Reston, 1992). The likelihood that the top of the lower crust is not a fixed boundary (discussed above) means that the restoration of the lower crustal section is only appoximate, but it is clear that the model provides a more reasonable restoration than that in fig. 2c). The removal of deep crustal extension along the west-dipping detachment system restores crustal thickness to about $31 \mathrm{~km}$ in the east (the site of the Devonian collapse of the Caledonian orogen - Cheadle et al., 1987), increasing gradually westwards to about $35 \mathrm{~km}$ beneath the foreland to the orogen. Most of the distortion of the lower crust is removed, and the antiformal reflections beneath the Outer Isles Fault (labeled 1 and 2), interpreted as updomed lower crustal shear zones, become west-dipping, subparallel features that cut down from the top of the lower crust towards the Moho and the Flannan Fault. The restored crustal section is thus consistent with that expected across the margin of a collapsed orogen.

\section{Discussion}

Le Pichon and Barbier (1987) propose a similar antithetic detachment system for the north Biscay Margin, but point out that such a system has not been reproduced in analog models. Thus, an obvious question to be explored is why the lower crustal detachment system developed antithetic to the block-bounding faults. One possible explanation is that the Permo-Mesozoic extension reactivated existing structures, both within the crust, and perhaps also within the mantle.

The reactivation of crustal structures is well documented in this region (e.g., Stein and Blundell, 1990). It is thought for instance that the Outer Isles Fault originated in the early Proterozoic, and has been reactivated at least three times (Lailey et al., 1989). Some of the other faults can be shown to have been active during Devonian extension (Enfield and Coward, 1987), and others may reactivate Caledonian structures (Cheadle et al., 1987). Thus the geometry of upper crustal extension was strongly influenced by pre-exixting structure.

The question then becomes why the extension was transferred to the west from the upper crust to the mantle. The simple explanation is that the mantle was weaker to the west than immediately beneath the Permo-Mesozoic basins. Even a small variation in mantle strength is sufficient to displace laterally mantle deformation (Dunbar and Sawyer, 1989).

We can only speculate as to the nature of a mantle weakness west of the profile. For instance, Carboniferous rifting in the Rockall Trough (Smythe, 1989) may have resulted in hot, weak mantle to the west of the profile. Alternatively, the Flannan Fault (fig. 2c)) might have acted as an extensional shear zone during the Permo-Mesozoic, concentrating mantle deformation into its footwall (Reston, 1990). In one combined scenario, the Flannan could have formed an extensional shear zone during the rifting in the Rockall Trough, and was subsequently reactivated during Permo-Mesozoic extension.

Warner suggests that the Flannan may represent a subduction zone rather than an extensional shear zone. He extends this interpretation to the sub-horizontal W reflector located in its hangingwall, that is in the mantle beneath the PermoMesozoic basins. Although it may be possible to reactivate a subduction zone as an extensional shear zone, the subduction zone hypothesis opens up another possibility for the role of these structures in lithospheric extension. Although we know of no literature comparing the strengths of eclogite (garnet and pyroxene) and peridotite (olivine and pyroxene), eclogite is likely to be stronger as garnet is stronger than olivine. Thus two slabs of eclogite could reinforce the mantle, making that beneath the basins unusually strong. Rather than extending the strong mantle directly beneath the basins, the extension of the mantle would instead be accommodated further to the west.

The key to understanding the extension of the lithosphere to the north of Scotland may therefore be to determine the nature of the Flannan. One way may be to investigate the nature of its interaction with the base of the crust. Although the Flannan is generally a fairly narrow band of reflections (fig. 1), on some profiles it appears to pass up into the lower crust as broad band of reflections (fig. 3a)), which then flatten to horizontal. Either the thick band of reflections pro- 


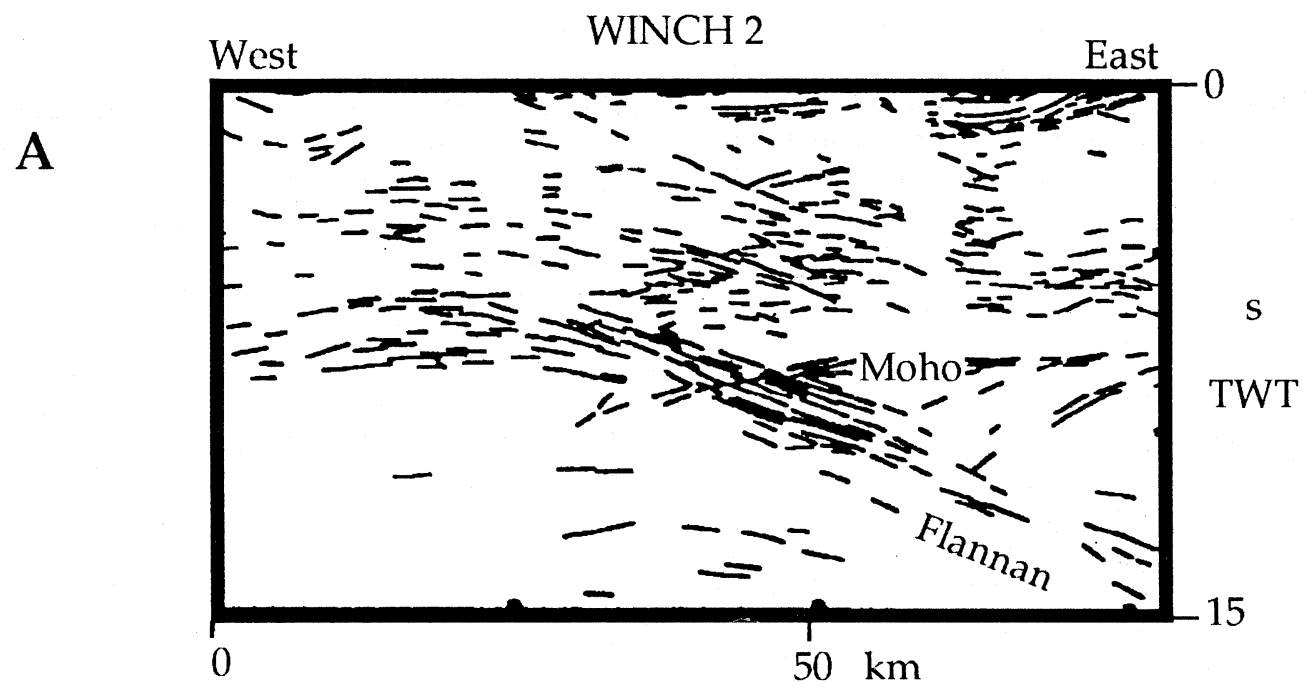

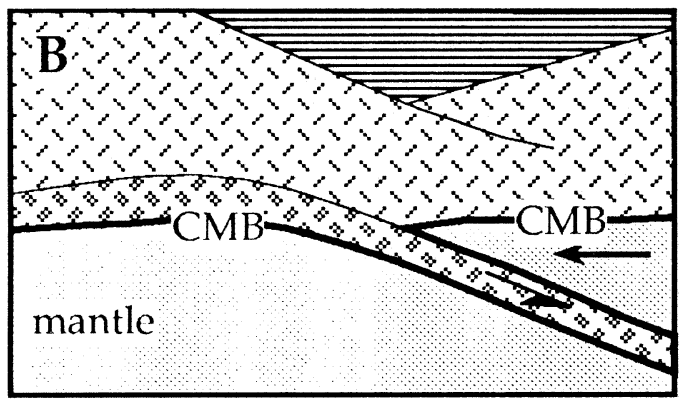

3 subducting crustal material

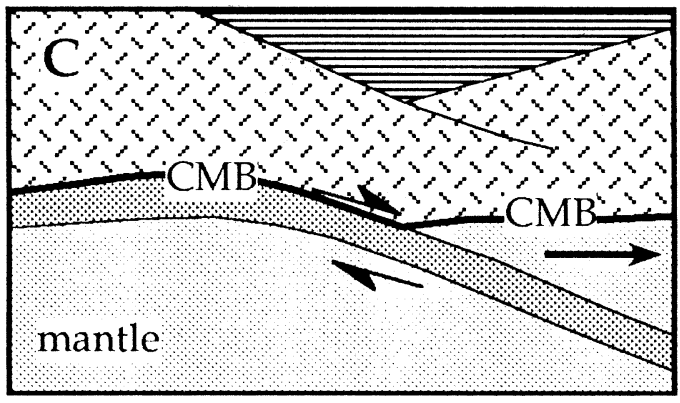

\%? sheared and intruded mantle

Fig. 3. Line-drawing (a)) after Warner (1986) of WINCH 2 north of Scotland (for location see fig.1) showing Flannan passing above the Moho. The relationships seen here can be interpreted in terms of deep crustal subduction (b)) or extension (c)). These make quite different predictions about the nature of the Flannan material (crust or modified mantle, respectively).

jecting into the mantle represents underthrust (subducted) crustal material (fig. 3b)), or the «lower crustal» reflections that are continuous with and west of the Flannan represent mantle material (perhaps heavily intruded - Reston, 1990), brought up by extensional shear along the Flannan (fig. 3c)). Thus the key to understanding the nature of the Flannan may be to determine the nature of this portion of the lower crust (Reston, 1990). Unfortunately no velocity information exists as yet, but a recent interpretation of gravity data (Snyder and Flack, 1990) suggests that this zone has physical properties consistent with heavily intruded (hence reflective) mantle, and thus that the Flannan is an extensional shear zone.

\section{Conclusions}

Simple stretching models do not satisfactorily explain the extension of the crust north of Scotland. The data are however compatible with the interpretation that extension was transferred to the west from the upper crust in the mantle along 
a west-dipping lower crustal shear zone. The cause of this is not clear, although the answer may lie in determining the nature of the Flannan Fault once and for all. The best way to do this is by investigating the velocity structure of this feature, both at depth in the mantle, and near its interaction with the base of the crust.

\section{REFERENCES}

BLOCK, L. and L. RoYden (1990): Core complex geometries and regional scale flow in the lower crust, Tectonics, $\mathbf{9}$, 557-568.

Cheadle, M., S. McGeary, M. Warner and D. Matthews (1987): Extensional structures on the western United Kingdom continental shelf: A review of evidence from deep seismic reflection profiling, Geol. Soc. London, Spec. Publ., 28, 445-466.

DUNBAR, J. and D. SAWYER (1989): How preexisting weaknesses control the style of continental breakup, $J$. Geophys. Res. B, 94, 7278-7292.

ENFIELD, M. and M. CowARD (1987): The structure of the West Orkney Basin, J. Geol. Soc., London, 144, 871-874.

JACKSON, J., N. White, Z. GARFUNKEL and H. ANDERSON (1988): Relations between normal fault geometry and vertical motions in extensional terranes: an example from the southern Gulf of Suez, J. Struct. Geol., 10, 155- 170.

KuszNIR, N. and D. MATTHEWs (1988): Deep seismic reflections and the deformational mechanics of the continental lithosphere, Petrology, Special Lithosphere Issue, 63-87.

KUSZNIR, N. and S. EGAN (1989): Simple-shear and pureshear models of extensional sedimentary basin formation: application to the Jeanne d'Arc Basin, Grand Banks of Newfoundland, A.A.P.G. Mem., 46, 305-322.
LAiley, M., A. SteIn and T. Reston (1989): The Outer Hebrides Fault: a major Proterozoic structure in NW Britain, J. Geol. Soc., London, 146, 253-259.

LE PICHON, X. and F. BARBIER (1987): Passive margin formation by low angle faulting within the upper crust: the northern Bay of Biscay margin, Tectonics, 6, 133-150.

MCGEARY, S. (1989): Reflection seismic evidence for Moho offset beneath the Walls Boundary strike-slip fault, $J$. Geol. Soc., London, 146, 261-269.

MEISSNER, R. and N. KUSZNIR (1987): Crustal viscosity and the reflectivity of the lower crust, Ann. Geophys. $B, 5 B$, 365-373.

REston, T. (1990): The lower crust and the extension of the continental lithosphere: Kinematic analysis of BIRPS deep seismic data, Tectonics, 9, 1235-1248.

Reston, T. (1992): Evidence for extensional shear zones in the mantle offshore Britain, and their implications for the extension of the continental lithosphere, Tectonics (in press).

SMYTHE, D. (1989): Rockall Trough-Cretaceous or Late Paleozoic? Scott. J. Geol., 25, 5-43.

SNYDER, D. and C. FLACK (1990): A Caledonian age for reflectors within the mantle lithosphere north and west of Scotland, Tectonics, 9, 903-922.

SteIn, A. and D. Blundell (1990): Geological inheritance and crustal dynamics of the NW Scottish Continental Shelf, Tectonophysics, 173, 455-467.

WARNER, M. (1986): Deep seismic reflection profiling the continental crust at sea, A.G.U. Geodynamics Series, 13, 281-286.

WARNER, M. and S. MCGEARY (1987): Seismic reflection coefficients from mantle fault zones, Geophys. J. R. Astron. Soc., 89, 223-229.

Wernike, B. and B.C. BuRCHFIEL (1982): Modes of extensional tectonics, J. Struct. Geol., 4, 105-115.

White, S. and J. Glasser (1987): The Outer Hebrides Fault Zone: evidence for normal movements, Geol. Soc. London, Spec. Publ., 27, 175-183. 